\title{
The Perils of Paradigm Maintenance in the Face of Crisis
}

\author{
Andrew Martin Fischer \\ Senior Lecturer of Population and Social Policy \\ International Institute of Social Studies of Erasmus University Rotterdam \\ 26 November 2009 \\ REVISED POST-CONFERENCE DRAFT \\ PLEASE DO NOT QUOTE WITHOUT THE AUTHOR'S WRITTEN \\ PERMISSION
}

\begin{abstract}
This paper addresses how Keynesian narratives are being used to reconstitute an orthodox policy paradigm in the face of the current economic crisis. Such ideological revisionism also occurred alongside the 1982 debt crisis and was crucial for the neoliberal ideological triumph that ensued. Similar revisionism can be observed now through narratives that locate the sources of the US financial bubble in Chinese external surpluses. This narrative has captured the imagination of many on both the political left and right, hence the potential for ideological reconstitution that cuts across traditional political positions in the North. These processes of paradigm maintenance need to be urgently addressed if the current crisis is to be leveraged for a return to a more progressive, inclusive and developmental policy paradigm in both North and South. Failing this, current orthodoxies risk being reconstituted or even reinforced, with the risk of finding ourselves soon entering a new round of development debacles similar to those of early 1980s.

Presented at the UNRISD conference on the "Social and Political Dimensions of the Global Crisis: Implications for Developing Countries," 12-13 November 2009, Geneva
\end{abstract}

Word count for the paper: 14,300 (16,000 with footnotes) 


\section{Introduction}

Two ideas have become new conventional wisdoms in the current economic crisis. One is that the mainstream economic consensus of the last decades has been shattered. Apparently, we are all Keynesian now. The other is that the turbulence that we have just travelled through has been beyond comparison to any other since the Great Depression. This latter comparison is poignant in its implicit evocation of the shift from UK to US hegemony in the international economic order. Many on both left and right suggest that the current crisis heralds a similar shift now, this time from the US to East Asia and possibly even to China.

Both suppositions can be questioned, not for the sake of provocation, but for the sake of remembering a more recent past as a guide to what might be soon around the corner. The more recent past in question is that of the 1960s and 1970s, which in fact bears much more in common with the current crisis than is normally accorded. This was the last time that US hegemony was seriously challenged and then aggressively revived through monetarism and militarism, effectively ending the 'Golden Age' of Keynesianism in the North and developmentalism in the South. The resulting economic policy package became known as neoliberalism or, in more innocuous terms, the 'Washington Consensus,' that is, the consensus that is now supposed to be shattered. Then as in now, we tend to assume that systemic crisis signals the end of hegemony. Then it did not. What guarantee is there now that it will? This indeterminacy remains mostly unacknowledged amidst a presumed determinism of current debates.

Much of the presumption derives from the illusion that we have already turned a corner and are returning to some form of Keynesianism, despite the rapid relapse into business as usual amidst an even greater concentration of corporate and financial power than before the start of the crisis. Moreover, there now seems to be a sober consensus among supposedly-humbled economists that public austerity must follow private bail out, supported by the convenient recollection that Keynes, after all, had not advocated for permanent deficits, only cyclical deficits to be balanced over the course of the business cycle. Yet, ironically, this Keynesian narrative has been usurped to a large extent by erstwhile propagators of the orthodox policy paradigm and, through a variety of rhetorical twists devoid of Keynes's most essential insights, is being used to reconstitute this orthodoxy in the face of the current economic crisis. This process of paradigm maintenance needs to be urgently addressed if the opportunity presented by crisis is to be leveraged for a return to a more progressive, inclusive and developmental policy paradigm in both North and South. Failing this, current orthodoxies risk being reconstituted or even reinforced. Through a sense of complacency that the 'consensus has been shattered' - a conventional wisdom common among both left and right - we risk finding ourselves soon entering a new round of radical systemic adjustments producing development debacles similar to those of early 1980s.

This argument is made in three parts. First, several contemporaneous debates are revisited concerning the lead up to the 1982 debt crisis, which marked a decisive turning point in US global hegemonic revival. In particular, the recasting of this crisis as primarily a problem of surpluses emerging from oil price shocks in the 1970s and subsequent borrowing by developing countries is discussed, along with the ideological implications of this recasting in terms of legitimising neoliberal responses. Second, the paper examines how the crisis today has been quickly framed by leading public 
economists, usually with platitudinous references to Keynes, as a problem of excess savings, particularly those deriving from Chinese surpluses, thereby deflecting attention away from the fact that the crisis is more accurately rooted in the recent phase of rampant financialisation intimately connected to the maintenance of US hegemony. The third section then discusses how this logic is profoundly un-Keynesian and an alternative explanation of the sequencing between US financial bubble and Chinese surpluses is provided. The conclusion explores some of the implications of this ideological reconstitution that is taking place before our very eyes even in the midst of the ongoing crisis and ironically in the name of Keynes, with very dubious implications for publics in both North and South.

\section{Revisiting the 1982 Debt Crisis}

Recalling the debates during the lead up to the 1982 debt crisis is important precisely because this crisis marked the decisive turning point of US global hegemonic revival, ending the slow erosion of US control on economic, political and military fronts during the troubled decade of the 1970s. It ushered in the 'changing of the guard' in key international financial institutions, replacing the earlier 'structuralist' (albeit pro-US) influence of Hollis Chenery in the World Bank with the 'neoliberal' ascendance of Anne Krueger. The tide also turned within the field of development studies, although not without much contention and resistance, through the forced shift of focus away from concerns regarding equity within growth to those regarding equity within stabilisation, adjustment and economic depression. The shift reflected the demise of developmentalism in most low and middle income countries outside South and East Asia, and of the Third Worldist activism and confidence that had been effervescing throughout the 1960s and 1970s. Most of Latin America, Africa and West Asia had been effectively disciplined through international finance in a way that could not be achieved through direct politics or military intervention, particularly following the US debacle in its war with Vietnam. ${ }^{1}$

Before this seismic shift in global geopolitical economy, it could not assumed that East Asia would so effectively overtake the Southern Cone of Latin America as the most advanced industrialised region of the Global South. Moreover, as with crises before and after, the regions of the South most affected were those that were most deeply integrated into the international (capitalist) economy, particularly the international financial system. As argued by Arrighi (2002:22-23), when the US government started to compete aggressively for capital worldwide in the early 1980s through a sharp increase in interest rates as a means to finance its growing current account deficits, the resultant reversal in the direction of global capital flows split the Global South into two regions; one that had a strong advantage in competing for a share of the expanding Northern demand for cheap industrial products and that had less need to compete with the US for international finance, and another that was put into the hopeless position of having to compete directly with the US in world financial markets. From this perspective, much of Latin America's curse, among other considerations, was that it was stuck in a middle-tier position in the global hierarchy, blocked from moving further up the value-chain into leading industries that were increasingly the preserve of highly concentrated corporate networks in the

\footnotetext{
${ }^{1}$ See Arrighi (2003) for an excellent overview of these dynamics. I am also deeply indebted to Kari Polanyi-Levitt for her insights on this period from a southern and, more particularly, a Latin American and Caribbean perspective.
} 
North. Alternatively, the other option was to compete downwards with the rising East Asian Tigers in low-wage manufacturing. ${ }^{2}$ The 1982 debt crisis and subsequent neoliberal policies arguably served, whether intentionally or opportunistically, as powerful mechanisms of subordination, thereby settling the choice.

Without entering into the intricacies of these mechanisms, it is nonetheless useful to recall certain stereotypes of this period which have since attained the status of truisms through the force of repetition, despite being the focus of debate and contention among leading economists at the time. Among these is the idea that inflation and increased international US dollar liquidity in the 1970s, and hence stagflation in the industriallyadvanced economies and the build up of debt by developing countries, was due primarily to the first oil shock in 1973, when OPEC quintupling the price of oil, followed by the subsequent recycling of petrodollars in the international financial system. Accordingly, the newly liberalised international financial sector had merely played its role as efficient mediator between these imbalances that were, ultimately, the result of market interventions by countries unable to absorb the surpluses resulting from their imprudent actions. This particular portrayal served an important legitimising role for the belief, famously edified by Thatcher, that 'there is no alternative' (TINA) to correcting the consequences of years of interfering with sound market principles.

While obviously containing elements of truth, this streamlined representation of imbalances in the 1970s can be called a stereotype because of its selective and partial representation of the systemic forces at work. This includes side-stepping the fundamental source of increased international dollar liquidity and inflation in the 1970s, which was located in US fiscal and monetary policy in the 1960s amplified through the increasing liberalisation of international banking in the same decade. Notably, the acceleration of both liquidity and inflation were well under way by the time of the first oil price shock in 1973. At the time, it was well recognised that this had been due primarily to persistent US fiscal deficits from the mid-1960s onwards, in part due to the expenses incurred by the Vietnam War combined with the end of 'east Keynesianism'. ${ }^{3}$ The resultant increases in liquidity were transmitted and augmented internationally by the liberalising offshore Eurodollar market. ${ }^{4}$ Indeed, the primary reason for the US going off the gold standard in 1971 was the unsustainability of its position in the context of persistent deficits and the increase in foreign claims on dollars and, hence, on US stores of gold. The radical move (in the perspective of the time) to a new regime of floating exchange rates also allowed the US to adjust its imbalances through devaluation, particularly with respect to rising competition from Germany and Japan. ${ }^{5}$

\footnotetext{
${ }^{2}$ For a similar version of this argument, see Mahon (1992).

${ }^{3}$ See Brenner (1998) and Arrighi (2003) for a debate on the causes and consequences of the slow down, with particular attention to the effects of 'uneven development', meaning the catch up of Germany and Japan with the US.

${ }^{4}$ See Kregel (2008) for an excellent discussion of the first major post-war expansion of international private finance that started with the credit crunch in the US in 1966. Also see an excellent recent historical survey in D'Arista (2009) and a succinct presentation of the evolution of international banking during this period in Shadlen (2006).

${ }^{5}$ Again, see Brenner (1998) and D'Arista (2009) on the US strategy of devaluation vis a vis its main industrial competitors. Arrighi (2003) extends Brenner's argument by including more consideration of broader geopolitical considerations, particularly with respect to the Global South.
} 
Thus, despite the intense debates at the time among both left and right about the exact reasons for stagflation, empirically it was very clear that the proximate vehicle of global inflation had been sharp increases in international dollar liquidity from the late1960s onwards. However, subsequent oil price shocks gripped popular imagination as the obvious and convenient scapegoat for inflation and slow down. Responding to such myopia, Robert Triffin (1978/79) wrote his seminal reminder in Foreign Affairs, noting that world 'import and export prices... rose by less than one percent a year in the 1960s, but by more than six percent a year from 1970 through 1972, and by as much as 30 percent in the last 12 months before the explosion of oil prices in the fall of 1973.' He argued that this 'was not unconnected, to say the least, with the enormous and mounting US deficits abroad which flooded the world monetary system, doubling world reserves from the end of 1969 to the end of $1972 \ldots$ increasing them by as much in this short span of three years as in all previous centuries in recorded history.'

This contemporaneous debate is worth recalling because it demonstrates the rapidity even then with which proximate events displaced the short-term memory of obvious underlying causes in the public political consciousness. For, as argued by Triffin and others, the oil price shock played a minor albeit aggravating role, contrary to popular and much academic perception and assertion at the time. Indeed, the OPEC cartel was in part an emergency response to the fact that, in the face of accelerating inflation in the industrially-advanced countries in the early 1970s, the terms of trade of petroleum exports had fallen to their lowest level since the 1930s. ${ }^{6}$ While the cartel was more than successful in correcting this decline, with the immediate effect of generating substantial surpluses for oil-exporting countries which they could not immediately absorb, many argued that these surpluses accounted for a relatively minor share of the increase in global dollar liquidity in the 1970s. ${ }^{7}$ While these surpluses did represent a sudden temporary restructuring of global imbalances, in any case, they were largely exhausted by the end of the 1970s. Despite popular perception at the time, surpluses accumulated by oil-exporting countries were not the main cause of global imbalances, although they definitely exacerbated these imbalances.

The main cause resided in expansionary monetary policy in the US and the ability of the US government to rely on its seigniorage rights, augmented by the revolution in international banking from the mid-1960s onwards, as mentioned above. In this context, debt accumulation became a norm in 1970s due to very low and sometimes negative real interest rates, ${ }^{8}$ combined with very abundant money and very bullish international bank lending operations right up to the eve of the debt crisis. ${ }^{9}$ Debtors obviously found advantageous incentives in this setting. In particular, governments and enterprises in credit-worthy middle-income industrialising countries were suddenly freed from the foreign exchange constraints that had been constraining them for several decades and from the periodic IMF adjustment programs that came as a result of these constraints,

\footnotetext{
${ }^{6}$ See reference to this in Toye (1993).

${ }^{7}$ See this view in Triffin (1978/79). Shadlen (2006) notes that net international bank lending far exceeded the amount of money deposited in banks by the OPEC countries. Of course, some of this excess could be accounted for by the very low reserve requirements of offshore banking, although, as pointed out by Shadlen, the net size of the Eurodollar market expanded by 15 times between 1965 and 1975 and then doubled from 1975 to 1980. Most of the increase in the first period occurred before the first oil price shock.

${ }^{8}$ See Palma (2003) for details on real LIBOR rates during this period.

${ }^{9}$ See Diaz-Alejandro (1984).
} 
which were highly unpopular and damaging for industrialisation. Notably, there was no particular ideological or political proclivity in this regard; right-wing military regimes in Chile and Argentina as well as socialist Poland, oil importers and exporters, many OECD countries and even South Korea had engaged in heavy borrowing during this El Dorado of cheap dollar liquidity, with the very proactive complicity of liberalised international banks. However, the fact that trade surpluses temporarily shifted to oil exporting countries nonetheless created a convenient scapegoat that has since been a recurrent theme into the present, in addition to the theme of irresponsible debtors.

On the latter point, it is important to recall that the Latin America debt bonanza only became a so-called 'Ponzi scheme' when the US radically changed the game in the early 1980s by sharply raising interest rates, up to a peak in the federal funds rate of 20 percent in June 1981. ${ }^{10}$ This single monetary strategy set off several simultaneous blows including: huge increases in interest payments; the drying up of new bank loans as the US soaked up liquidity from around the world; massive capital flight from South to take advantage of high interest rates in guaranteed US government securities, exacerbated by a strong commitment among Latin American governments to maintain full convertibility; and a fall in demand and terms of trade for Southern exports due to recession in North America and Europe. ${ }^{11}$ The resulting collapse among the large Latin debtors, starting with Mexico in 1982, created a serious threat to the stability of the US financial system given the high degree of exposure of most of the largest US banks. ${ }^{12}$ In the murky waters of the lead-up to crisis, it is clear that responsibilities and potential risks were shared by creditors and debtors alike, as well as by North and (Latin) South. However, in hindsight we know that the costs were mostly borne by the latter, to the extent that Latin American governments willingly or unwillingly socialised large amounts of privately-contracted debt and adopted stabilisation policies that quickly generated trade surpluses by crippling their economies in order to service these socialised debts. ${ }^{13}$ For the first time in the history of Latin American debt crises, there was little if any sustained default.

From the perspective of Northern finance, this outcome was a resounding success compared to how things could have been. However, it is also clear that the narrative of placing singular blame of financial irresponsibility on the Latin debtors served an ideological role to justify the fact that Northern financial sectors escaped the crisis relatively unscathed, albeit at massive social costs to Southern publics. It also served to divert blame in the North, where workers were also suffering under the highest unemployment rates witnessed since the Great Depression (still higher than rates witnessed so far in the current US crisis, although arguably the official definition of unemployment has been considerably eroded since the early 1980s). To borrow the

\footnotetext{
${ }^{10}$ There were nonetheless some strong doubts being expressed around 1980 about the sustainability of the debt loads being accumulated. For instance, see the assessment in Frieden (1981). This was most likely due to the fact that interest rates started to rise under Carter/Volcker in 1979 as a means to stave off a run on the dollar (see Arrighi 2003). However, these doubts were too little too late and did little to dampen the lending euphoria right up to the eve of the crisis, similar to the final binges of international financial speculation in the recent crisis, such as the international carry trading by hedge funds that continued right up to the outbreak of the crisis in 2007 and even into 2008 and are currently resurging again.

${ }^{11}$ See Diaz-Alejandro (1984) for detailed analysis of these four aspects of the crisis.

${ }^{12}$ For excellent discussions of this and related financial events, see Kregel (2008) and Dymski (2008). Also see Shadlen (2006).

${ }^{13}$ Again, see Diaz-Alejandro (1984) for an excellent discussion of this. Also see Fischer (2009b).
} 
opening words of the seminal analysis of the debt crisis by Carlos Diaz-Alejandro (1984), 'Blaming victims is an appealing evasion of responsibility, especially when the victims are far from virtuous' (ibid:335). He elaborated;

But when sins are as heterogeneous as those of the Latin American regimes of 1980, one wonders how well the exemplary mass punishment fits the alleged individual crime. Most Latin American economies, for a variety of domestic and external reasons, in 1980-81 faced the need for reform and adjustment to the new international economic environment... Yet the incompetence and torpor of policymakers do not fully explain the depth of the depression of the early 1980s in Latin America... what could have been a serious but manageable recession has turned into a major development crisis unprecedented since the early 1930s mainly because of the breakdown of international financial markets and an abrupt change in conditions and rules for international lending (ibid).

The hypocrisy of the new orthodoxy was especially notable; in the name of stabilisation, Southern economies were effectively haemorrhaged, which no doubt supported economic recovery in the North from 1983 onwards with the contribution of fleeing capital from the South. This was highlighted by Diaz-Alejandro. After a discussion of the local political economy reasons why Latin American elites supported and in some cases even encouraged stabilisation and adjustment measures, he concluded;

The international system as it stands circa 1984 has encouraged the erosion of legitimacy of a mixed economic system in Latin America, and not just by offering extravagant real interest rates, safety, and numerous tax havens. Pressures were brought upon countries to socialize private external debt ex post and to support private local firms with debts abroad. External debts of all sorts have increasingly been brought into the definition of the debt of nations with the presumption that all debt, public or private, is the responsibility of the whole country and of the current government... Behavior not permitted to domestic citizens [by the US] is encouraged among foreigners (379).

In this context, the subsequent diversion of focus onto the irresponsibilities of Latin American governments in the crisis, as has been common in crises ever since, amounted to a form of rhetorical opportunism tautologically focusing on the symptoms of crisis as if these were the principle causes of the crisis. Policy advices followed suit in similar fashion, as represented by the reply to Diaz-Alejandro by the young Jeffrey Sachs, who argued that the IMF focus on reducing budget deficits through austerity was a crucial step for restoring private-sector confidence in local currency assets (Sachs:399-400).

The power of the monetarist ideological response to this crisis was precisely that it simultaneously succeeded in placing the blame of instability and imbalances on the most obvious surplus culprits (oil exporting countries), while legitimising policies that shifted the burden of systemic adjustment onto the most industrially-advanced and integrated peripheries of the international system. At the same time, Northern economies profited from the stimulus created by the routing of these peripheries. This ideological response was subsequently embodied in structural adjustment programmes (SAPs), which more generally reflected the needs of the structural realignment of the international economic order from the 1980s onwards, i.e. a shift in external position of the US from 
current account surpluses up to the 1970s to persistent and rapidly growing current account deficits from the late 1970s onwards. The debt crisis was arguably one of the key mechanisms that allowed for the reassertion of US hegemony on this entirely new structural footing, through financial means combined with a massive return to militarism under Reagan from 1983 onwards. ${ }^{14}$ It is in this sense that the neoliberal policy package is best understood as a disciplinary device - there is no other reason why pro-cyclical policies would be advocated in the face of an economic crash.

The emergent neoliberal consensus of the 1980s thereby managed to recast its policy failures in dealing with the 1982 debt crisis into ideological triumph. In particular, the air was knocked out of oil prices by world recession combined with the desperate need for foreign exchange among major petroleum producers such as Mexico, Venezuela and Nigeria. The failure of Latin America and then Africa to quickly rebound from intense economic depression was taken as proof of the need for structural adjustment in the first place (and later, under the Post-Washington Consensus, of the need for institutional reforms). This revisionism in the face of systemic crisis was so successful that the resulting narrative is rarely challenged or questioned in the mainstream development studies literature today, even by many scholars on the left. Indeed, it is often noted that the current crisis is the first major crisis since the 1930s to have emerged from the centre rather than the peripheries, even though the 1982 debt crisis was arguably also an outcome of building disequilibria emanating from the centre.

\section{Of US credit bubbles and excessive Chinese savings}

Debates on the current financial crisis have been intense and ongoing, particularly among economists intent on squirming out from under the burden of responsibility with the convenient refrain that no one saw it coming (besides those whose work was being ignored by the mainstream). While this parody has captured the attention of the highbrow popular press for having seemingly dethroned the arrogance of the economics high church, ironically, it has been serving as an effective distraction from ideological reconstitutions simultaneously taking place in the midst of crisis. The double irony is that these reconstitutions are usually couched in loosely substantiated evocations of Keynes.

As if a refrain, the narrative is again focused on blaming the peripheries for crisis in the centre. The target is again the most obvious surplus country; China. The charge is that its interventionist economic strategies and its understandable but mistaken obsession with amassing foreign exchange has been an important, if not dominant, underlying cause of the credit bubble in the US. The logic is that a foreign exchange savings glut emanated from Asia as an outcome of specific policy choices taken in the aftermath of the East Asian crisis of 1997-98. This savings glut was then recycled in the US given that most foreign exchange reserves are held in US Treasury securities or, increasingly, in nongovernment investments including the notorious securitised subprime mortgages. Hence, the Asian savings glut crucially fuelled the US credit bubble. The Keynesian allusions are presumably based on the idea that such savings will ultimately be self-defeating whence bubble comes to bust and that surplus countries should be penalised. China in particular must now make painful adjustments to correct its previous policy blunders, not only by contributing to stabilising the international financial system, but more fundamentally by

\footnotetext{
${ }^{14}$ See Arrighi (2003) for a powerful argument along these lines.
} 
allowing its currency to appreciate and by liberalising its financial sector in order to end the repressed consumption of its citizens.

In order to clarify the logical steps of this narrative in more detail, it is useful to focus on the columns of Martin Wolf from the Financial Times, given that he represents a powerful voice in its popularised propagation. Notably, at the end of 2008, Wolf (2008) iconically alluded (without attribution) to the famous quote by Milton Friedman that 'we are all Keynesians now,' referring to the apparent shattering of the consensus which, it should be recalled, he had supported until it became obvious that the party was ending in 2007. The new consensus, he argued, was a return to a more balanced approach between the choices of laissez-faire (he did not use this precise term but implied it) and socialism (he did use this term, referring to strong forms of state intervention in the economy, not actual socialism). It was of course the convenient argument to make at a time when there was mounting political pressure to nationalise failing financial institutions in the UK, as opposed to the massive bail-outs that were already in motion.

In this column, Wolf (2008) summarised three broad lessons of Keynes. First, markets are not necessarily efficient (or that we should not take the pretensions of financiers seriously). Second, the economy cannot be analysed the same way as a firm (i.e. aggregates do not necessarily operate in the same way as their parts). Third, the '...most important lesson is that one should not treat the economy as a morality tale.' The first two are open to ambiguity and interpretation; the important question is not whether markets are inefficient, which even economists such as Deepak Lal accept, but why. However, Wolf's third lesson is the most revealing of his revisionist reading of Keynes, given that Keynes arguably did in fact see the economy as a morality tale. For instance, in 'The Economic Consequences of Mr Churchill' he argued against the idea that a selfregulating financial regime functioned with technical neutrality, but pointed instead to a class bias that is 'deeply embedded in our system of money contract' (cited in Polanyi Levitt 2006:165). Wolf thereby completely sidestepped Keynes' conviction that unregulated finance would destroy capitalism. Even more importantly, Wolf omitted all mention of employment and wages in his lessons despite the fact that it was precisely unemployment and the perverse idea that wages should fall as a means to correct unemployment that was perhaps the strongest force driving Keynes' intense commitment to overturn economic orthodoxy in England as it stood in the early 1930s (and as it has stood over the last 30 years).

Instead, Wolf (2008) directed his attention to the issue of rebalancing global demand. Beyond his case for a fiscal response to the crisis, his focus on global imbalances appeared to be his other claim to Keynesianism given Keynes' own efforts at the end of his life to create a balanced post-war international trading and financial system that would penalise surplus as well as deficit countries. ${ }^{15}$ From his own side, Wolf appeals to the idea of constructing 'a new system of global financial regulation and an approach to monetary policy that curbs credit booms and asset bubbles...' Alluding also to Minsky, he argues that '...recognition of the systemic frailty of a complex financial system would be a good start.' He did not provide more guidance at this point, besides pre-empting criticism by suggesting that we must meet this task '...in a spirit of humility and pragmatism, shorn of ideological blinkers.'

\footnotetext{
${ }^{15}$ Wolf is not explicit about this specific claim to a Keynesian legacy; I am giving him the benefit of doubt that this is what he implies.
} 
The idea of a stable financial system free of credit bubbles carries enormous appeal. Indeed, it is the stated objective of ardent neoliberals and socialists alike, as well as of most economic theorists in between. The more important question concerns how such bubbles came to be and thus how they can be undone. Wolf elaborated on this in later columns by turning his attention to China as a primary source of savings glut. For instance, in June 2009 (see Wolf 2009a), he set out a standard argument about the transmission of a global savings glut to financial debacle in the US. Citing a publicallyunavailable paper from Goldman Sachs, he reasoned that a global savings glut had driven two salient features of the global economy leading up to the crisis; a huge increase in global current account imbalances (especially the emergence of huge surpluses in emerging economies) as well as a global decline in nominal and real yields on all forms of debt. Conferring with the unidentified Goldman Sachs authors, he dismissed the argument that loose monetary policy had been driving these rising imbalances and falling yields because it 'fails to explain persistently low long-term real rates.' He listed the two remaining salient features identified by the Goldman Sachs paper (an increase in global returns on physical capital and an increase in the equity risk premium) and then added one of his own; 'the strong downward pressure on the dollar prices of many manufactured goods'. These, he argued, are additionally explained by a massive increase in the effective global labour supply and the extreme risk aversion of the emerging world's new creditors. In turn, this led to the accumulation of net overseas assets, entirely accounted for by public sector acquisitions and principally channelled into reserves.

Wolf (2009a) added that Asian emerging economies (China, above all) have dominated such flows. He attributed this fact, along with his fifth salient feature (downward pressure on dollar prices of manufactured goods), to policy decisions, particularly China's exchange-rate regime. Thus, he wrapped the plot together by centring in on China;

The decision to keep the exchange rate down also put a lid on the dollar prices of many manufactures. I would add that the bursting of the stock market bubble in 2000 also increased the perceived riskiness of equities and so increased the attractions of the supposedly safe credit instruments whose burgeoning we saw in the 2000s. The pressure on wages may also have encouraged reliance on borrowing and so helped fuel the credit bubbles of the 2000s.

Concurring with the unidentified Goldman Sachs authors, he argues that ...the low bond yields caused by newly emerging savings gluts drove the crazy lending whose results we now see. With better regulation, the mess would have been smaller... But someone had to borrow this money... This is as much a macroeconomic story as one of folly, greed and mis-regulation.

He concluded that 'China's decision to accumulate roughly $\$ 2,000 \mathrm{bn}$ in foreign currency reserves was... a blunder...' and it now has to accept the consequences in the quest for global rebalancing, particularly if it does not want to face default from its debtors (i.e. the US) no longer able to consume Chinese surpluses through further borrowing. In order to do this, China must, above all, correct its exchange regime. 
Wolf (2009b) reaffirmed this argument later in September. He remarked that it is no wonder the huge exposure of over 2 trillion dollars worth of foreign currency reserves makes the Chinese government nervous. However,

...nobody asked the Chinese to do this. On the contrary, US policymakers have consistently (and wisely) advised them to do the opposite. Having made what I believe was a huge mistake, the Chinese government cannot expect anybody to save them from its consequences. A substantial appreciation of the Chinese currency is inevitable and desirable in the years ahead. The longer the Chinese authorities fight it, the bigger their losses (and the pain of adjustment) are going to be.'

This time he conferred with a paper by Goldstein and Lardy (2009), published by the 'nonpartisan' Washington-based Peterson Institute for International Economics, that currency appreciation would also help rebalance the Chinese economy in the long term, among other policies such as further financial reform. He argued that an appreciation of the real exchange rate, 'ideally via a rise in the nominal exchange rate,' is the primary means to end China's 'massive subsidy to its exports' through its 'foreign currency interventions, combined with the sterilisation of their natural monetary effects.' This in turn would also serve to increase consumption as a share of GDP. On 17 November, during Obama's visit to China, Wolf (2009c) again stepped up this tone of urgency, insisting that the 'US is entitled to protect itself against such mercantilism... We have spent long enough discussing China's exchange rate policies. It is time for action.'

It is not unsurprising, given Wolf's posturing since the beginning of the crisis, that this is more or less the same position taken by the Obama administration, and even the Bush Junior administration for that matter. Indeed, one of the first acts of Tim Geithner as US Treasury Secretary was to declare China a currency manipulator in January 2009, although he quickly stepped down from this very aggressive stance. Notably, the Bush administration had been previously toying with this threat for several years but had not yet taken a stand. Similarly, on 19 October 2009, the US Federal Reserve Chairman Ben Bernanke argued that Asia must guard against a return to global imbalances in the economic rebound (see Guha 2009), even while Asia was being simultaneously thrashed by what has been called 'the mother of all carry trades' by Nouriel Roubini, stemming largely from current liquidity conditions in the US (see RGE 2009). Bernanke claimed that the US-centered crisis had been fuelled by giant capital inflows that overwhelmed both market discipline and regulatory safeguards against the mispricing of risk. In other words, similar to Greenspan before him, his interpretation of causality runs from surpluses to capital inflows and then to liquidity and regulatory failure, albeit Greenspan never made it to the last point during his tenure as Fed Chair given his avowed belief in the sophisticated ability of US financial markets to absorb such liquidity. Bernanke qualified this belief in line with the more dire times. However, his contention was similar, in that the East Asian push into export-driven growth and trade surpluses following their experience with the 1997 crisis subsequently produced imbalances between national savings, consumption and investment. Hence, while leading the rebound, China should work towards preventing a return to surpluses and asset bubbles. One way to mitigate this risk would be 'through some greater exchange rate flexibility' offset by fiscal consolidation. 
Some otherwise critical 'liberal' aka 'left' economists have possibly reinforced this narrative by also explaining the crisis as a problem of excess savings. For instance, Paul Krugman, the flag bearer for the 'New Keynesians' in the US, ${ }^{16}$ also places emphasis on China's exchange regime. In April 2009 he recounted that in

...the early years of this decade, China began running large trade surpluses and also began attracting substantial inflows of foreign capital. If China had had a floating exchange rate — like, say, Canada — this would have led to a rise in the value of its currency, which, in turn, would have slowed the growth of China's exports.

But China chose instead to keep the value of the yuan in terms of the dollar more or less fixed. To do this, it had to buy up dollars as they came flooding in. As the years went by, those trade surpluses just kept growing — and so did China's hoard of foreign assets (Krugman 2009a).

He argued that such habits must change; 'Two years ago, we lived in a world in which China could save much more than it invested and dispose of the excess savings in America. That world is gone... The bottom line is that China hasn't yet faced up to the wrenching changes that will be needed to deal with this global crisis. The same could, of course, be said of the Japanese, the Europeans — and us.' Krugman (2009b) explained this further in a related blog by clearly identifying the current crisis as a liquidity trap, in which we are faced with an incipient excess supply of savings even at a zero interest rate. 'In this situation,' he explains, 'America has too large a supply of desired savings [his emphasis]. If the Chinese spend more and save less, that's a good thing from our point of view. To put it another way, we're facing a global paradox of thrift, and everyone wishes everyone else would save less.' Again, the so called New Keynesian credentials of this argument seem to be based on an idea of excess savings that do not adjust to aggregate demand but instead keep sloshing around the system.

While he was more parsimonious with his blame in these springtime blogs, Krugman (2009e) nonetheless came out much stronger against China in his op-ed of 22 October 2009, in line with the position of Bernanke and Geithner mentioned above. He claimed that 'China's bad behavior is posing a growing threat to the rest of the world economy. The only question now is what the world - and, in particular, the United States — will do about it.' He argued that this policy made sense up to around 2001, although after this time 'the policy of keeping the yuan-dollar rate fixed came to look increasingly bizarre.' It is interesting to note that in his subsequent discussion of how this resulted in the effective devaluation of the yuan as the dollar slid in value, he omitted any recognition of the revaluation of the yuan from 2005 onwards, as discussed in the next section. Instead, he concluded that devaluation resulted in a huge Chinese trade surplus and added that many 'economists, myself included, believe that China's asset-buying spree helped inflate the housing bubble, setting the stage for the global financial crisis. But China's insistence on keeping the yuan/dollar rate fixed, even when the dollar

\footnotetext{
${ }^{16}$ See Krugman (2009c; 2009d). In the so-called 'New Keynesian' interpretation of Keynes, the General Theory has been transformed into a special case of sticky wages, solidly re-rooted in a neoclassical framework of analysis that, by definition, can only conceive of unemployment or other 'market failures' as deriving from market imperfections rather than from the something inherent to the aggregate mechanisms of free market operations. Krugman (2009d) implicitly defends this interpretation of Keynes, although in Krugman (2009c) he also recognises the internal contradictions of this position. However, he appears to have a poor understanding of post-Keynesian interpretations.
} 
declines, may be doing even more harm now.' He therefore encouraged a more bullish approach from US officials with regard to negotiations with China on currency manipulation. Helping to set the tone later asserted by Wolf, he insisted that 'with the world economy still in a precarious state, beggar-thy-neighbor policies by major players can't be tolerated. Something must be done about China's currency.'

A similar narrative has found a hold even further to the left. A strong example is found in Robert Wade (2009). This is somewhat paradoxical given that he usually opposes Martin Wolf on most issues, but here he seems to find an affinity in the savings supply-side interpretation of the crisis. He argues that ...global imbalances have had an important causal role not at the international level, in the form of currency recycling, but at the domestic level, in the form of credit recycling to the agents spending more than their income, who are the other end of the external deficit. The breakdown occurred in the credit recycling mechanism. (542-43)

He draws attention to the fact the US fiscal deficit fell as a share of GDP after 2003, leading to a ballooning private sector and current account deficit. He seems to imply that this had to happen given the global imbalances. The shift was facilitated through 'credit recycling to the private sector,' which

...took the form of capital inflows going mainly into mortgage finance (for example, the central bank of China bought the securities issued by the government-backed mortgage lender Freddie Mac), creating a real estate boom, which enabled households to convert capital gains into consumption in excess of their incomes via extraction of equity, on a massive scale relative to GDP. The build up to crisis happened as this credit recycling mechanism ran out of control... (ibid: 543).

He offers this perspective as a way to explain why 'the "mistakes" in monetary policy and financial regulation were made' (he implies they were the consequence of global imbalances) and why the crisis resulted in a run into the dollar rather than away from it (again, presumably for the same reason). Hence he concludes that global imbalances are too important to ignore; 'the current policy responses nationally and internationally are focused too narrowly on the financial system and not enough on the imbalances and what lies behind them...' (ibid: 543).

Through this logic, Wade actually finds himself quite close to the position of Wolf, arguing that much more is needed than simply correcting mistakes in monetary policy and financial regulation, although he does not explicitly spell out what this should entail for China (e.g. see pp.550-51). While he repeatedly quotes Keynes and evokes Keynesian remedies, it is interesting that his streamlined interpretation of the crisis, condensed into a mere page of text, seems to rest on an understanding of causality running from global imbalances to credit recycling. If so, his argument is essentially in line with that of Wolf, Bernanke and Krugman.

It is precisely this de facto consensus across much of the left and right that provides the potential for a powerful ideological reconstitution. Perhaps the guise of the reconstitution would not exactly match the neoliberalism that the left so despises, but it would effectively legitimise a strategy of shifting the burden of adjustment onto the most obvious peripheral surplus country that, in the end, is not even a serious industrial contender but instead is deeply integrated into regional and international production 
networks increasingly dominated by Northern corporations. In other words, despite the attention to global imbalances, these narratives ignore the underlying structures of production, distribution and ownership - or of power - that drive these imbalances. Indeed, from this latter perspective, the current crisis could well represent an important milestone in the seismic reorganisation and consolidation of these international production networks. If this were the case, it is quite possible that repressed wages in America and trade surpluses in China are both symptoms of larger global forces at work, encompassing both financialisation in the centre and network reorganisations in East Asia since the 1997-98 crisis.

\section{Keynes in Beijing}

In order to understand the last point, it is important to question whether these emerging narratives have understood the causality the right way around. Is it the case that emerging market surpluses have been generating a savings glut that is then transmitted and amplified through the financial sector to the US? According to this logic, the US financial sector might not be efficient in the sense of avoiding bubbles, but it definitely does its job with a vengeance, even if somewhat hectically. However, it could not do this job if the global imbalances had not provided a source of liquidity to slosh.

Despite the ritualised claims on the intellectual soul of Keynes that have become a litany accompanying these narratives, the underlying logic is profoundly un-Keynesian. To borrow the words of Geoff Tily, from a Keynesian perspective the logic amounts to the tail wagging the dog. ${ }^{17}$ In other words, it is based on the principle that supply creates its own demand (i.e. Say's Law). To frame this in the current discussion, Asian savings drive US aggregate demand. Or, in the words of Wolf (2009a), '...someone had to borrow this money...' Or, as argued by Wade, if 'the external deficit remains constant (or rises) and the fiscal deficit falls, there must be an offsetting increase in private indebtedness' (Wade 2009:542). ${ }^{18}$ This logic helps to clarify why both Wade and Wolf argue that the crisis cannot be fully explained by 'folly, greed and mis-regulation' (Wolf 2008) or by ““mistakes” in monetary policy and financial regulation’ (Wade 2009).

Keynes would have rejected this logic. Indeed, it was precisely this logic that was at the heart of his rejection of what he called 'the classics'. Instead, he argued that aggregate savings adjust to aggregate demand, not the other way around. To translate this into the current context, US aggregate demand drives US external imbalances, which in turn drive the imbalances of those economies oriented towards servicing US demand, primarily through investment demand in those economies, to which aggregate savings adjust. Changes in US aggregate demand are influenced by deficit spending, which in turn is influenced by warmongering and ideological obsessions with cutting taxes and subsidising the wealthy, and by private demand augmented by phases of financial

\footnotetext{
${ }^{17}$ Geoff Tily made this point during the question period that followed a talk by Prabhat Pranaik at London School of Economics in July 2009 in which he was a discussant. He later clarified in an email correspondence that he was paraphrasing a passage from a paper written by Keynes in 1932, in which Keynes explained that ' $\ldots . . S^{\prime}$ [aggregate savings] always and necessarily accommodates itself to I. Whether I consists in housing schemes or in war finance, there need be nothing to hold us back, because I always drags $S^{\prime}$ along with it at an equal pace. $S^{\prime}$ is not the voluntary result of virtuous decisions. In fact $S^{\prime}$ is no longer the dog, which common sense believes it to be, but the tail ...' (cited in Tily 2009:12)

${ }^{18}$ To give Wade the benefit of the doubt, it is not clear whether, in making this point, he implies causality or is simply clarifying an accounting identity.
} 
deregulation, innovation and resultant credit bubbles. ${ }^{19}$ In other words, another phase of rampant financialisation in the centre drives global imbalances. Placing this in the context of China, China's investment rates are not high because the Chinese save a lot. Rather, China's aggregate monetary savings (which includes credit from the banking system as well as finance from abroad, as discussed below) are high because of high rates of investment, which are in part responding to aggregate demand from the US and Europe, among other factors. China's growing external surpluses and building foreign exchange reserves are outcomes of these processes rather than causes.

There is a strong case to be made that this Keynesian interpretation fits the historical stylised facts quite well, at least much better than the supply-side (neoclassical) interpretation. To start with, it is important to recognise that the Chinese authorities have been keenly aware of the dilemma of the low consumption to GDP share for much longer than is typically acknowledged by western commentators. ${ }^{20}$ Raising this share has been an explicit goal of the government since at least 2003 if not before, such as in 1998 when one of the first reactions of the government to the East Asia crisis was to boost domestic demand. It has since been a subject of much domestic debate. For instance, Hu Angang, a prominent and influential economist based at Tsinghua University in Beijing, had vigorously argued for much greater emphasis on rural and agricultural development and on improving household incomes versus aggregate economic output as a means to deal with both sluggish domestic demand and rising regional inequalities (see $\mathrm{Hu} 2000$ ). He was an important proponent of major policy initiatives such as the Open the West Campaign (Ch. xibu da kaifa), which was adopted by the Central government in 2000 and has since had a significant impact on reversing inter-regional inequalities (although arguably at the cost of exacerbating intra-regional inequalities within West China). ${ }^{21}$ However, these and many more massive national efforts have been to no avail in raising the consumption share, which continued to fall in the 2000s.

The failure to achieve this goal of lowering the investment share of GDP can hardly be called a 'choice,' or if so, it has been a choice without any obvious or desirable alternative. It is not the case that, as suggested by Krugman (2009a), 'China acquired its \$2 trillion stash - turning the People's Republic into the T-bills Republic - the same way Britain acquired its empire: in a fit of absence of mind. And just the other day, it seems, China's leaders woke up and realized that they had a problem.' However, Krugman is probably right in his contention that there was not necessarily a deep strategy behind this vast accumulation of low-yielding assets. Indeed, in recognising its inability to balance its external position, the central government quickly and very consciously opted for the contingency option of at least managing the imbalances through sterilisation. ${ }^{22}$ Their choice to ride the wave of regional and global economic restructuring is understandable. Balanced or not, growth was nonetheless a priority given the enormous challenges facing

\footnotetext{
${ }^{19}$ See Dymski (2009) and Kregel (2008) for excellent discussions of these financial processes.

${ }^{20}$ Wolf (2009b) acknowledges this, but only with regard to the present context, not with regard to the longevity of these concerns.

${ }^{21}$ For a general analysis of 11 western provinces and a more detailed analysis of Sichuan, Gansu, Qinghai and Xizang under the Open the West Campaign, see Fischer (2005; 2007; 2009a).

${ }^{22}$ See Sun (2009) for a very interesting discussion of monetary policy in China, in particular its use of sterilisation as a means to regulate money supply in the context of imbalances.
} 
China, still a poor country, including fairly high levels of urban unemployment, ${ }^{23}$ persistent rural poverty (which is not so much a problem of repressed consumption but of low productivity), ${ }^{24}$ and, in this context, the planned urbanisation of the about one-third of the country's population over the course of the next generation, already in motion since the late-1990s. Given these pressing priorities, if growth could not be consumptionled (albeit consumption has been rising rapidly, just not as fast as investment), then it must be investment-led, not merely by choice but by necessity.

Moreover, the common assertion that China's high savings rate derives from high household savings, which in turn drive investment versus consumption, is another caricature worthy of some attention. The usual argument is that high household savings rates are in large part 'precautionary,' meaning that they are due to rising health and education costs and lack of social security and public pensions. The other argument is that high personal savings rates are also caused by policies of financial repression. For instance, Wolf (2009b) argues that ' $\mathrm{n}]$ ot the least of the distortions of the current regime is the need to keep interest rates low, to curb capital inflows. This shifts massive amounts of income from households into corporate profits.' In a more sophisticated analysis reminiscent of earlier attacks on East Asian industrial policy in the 1990s, Pettis (2009) argues that the fundamental cause is found in;

...industrial polices which were aimed at turbo-charging economic growth. These policies systematically forced households implicitly and explicitly to subsidize otherwise-unprofitable investment in infrastructure and manufacturing. Although these policies powered employment and manufacturing growth, they also led to wide and divergent growth rates between production and consumption.

These policies include an undervalued currency (which reduces real wages by raising the cost of imports), excessively low interest rates (which forces depositors - mostly households - to subsidize borrowers - mostly manufacturers), a large spread between deposit and lending rates to recapitalise banks suffering from bad loans, sluggish wage growth, unravelling social safety nets and other direct manufacturing subsidies. Thus, by

\footnotetext{
${ }^{23}$ See Hussain (2003:22-24) for an excellent discussion of urban unemployment in China. By adding 'laidoff' employees (Ch. xiagang zhigong) to the officially-registered unemployed and using the part of the urban workforce to which these unemployed refer as the denominator (i.e. the formally-employed 'staff and workers' + 'registered unemployed', because other urban workers do not qualify for treatment as 'laid-off employees' and, being outside the scope of unemployment insurance, they do not they have any particular incentive to register as unemployed), he estimates from official data an unemployment rate of 12.3 percent in 2000, versus the official rate of 6 percent. He argues that, although 'partial and subject to errors, this figure presents a more accurate picture of unemployment (meaning without a full-time job) in urban areas...' and he notes that while 'there is no reliable estimate of unemployment in the labour force that is not included in the category "staff and workers" [almost half the workforce of long-term urban residents], there are good grounds for assuming that the unemployment rate amongst them is no less than that for "staff and workers" [give that their] jobs are less secure than those of "staff and workers".' (ibid:23-24)

${ }^{24}$ Hutton (2007) makes the ridiculous assertion that the repressed consumption of rural residents in China has been funding the high rates of investment in China. This argument is about twenty years out of date, presumably referring either to Maoist policies or else to critiques of the dual price system in the 1980s. Ironically, as the dual-price system was being phased out in the early 1990s and most prices for agricultural commodities were being liberalised, from 1996 onwards market prices actually fell below the government guaranteed purchase prices (see Hussain 2002:64-65). Since this time, low agrarian incomes have been a combination of low labour productivity in agriculture with depressed market prices for the output of this productivity. It is no longer an issue that the government artificially represses prices for rural output.
} 
...transferring wealth from households to boost the profitability of producers, China's ability to grow consumption in line with growth in the nation's GDP was severely hampered. Of course the gap between production and consumption is the savings rate, and as production surged relative to consumption, a necessary corollary was a rising Chinese savings rate. The basic problem, then, is that there are very powerful policies that force a discrepancy in production and consumption growth, and the only way to eliminate overcapacity is by reversing these policies. I am not sure that attempting to address overcapacity by administrative means can succeed, and certainly the track record of other efforts over the past year to address the imbalance doesn't suggest otherwise (ibid).

Accordingly, reversing policies by non-administrative means would seem to imply allowing the yuan to appreciate according to market forces rather than through carefully regulated state management, as well as financial liberalisation to allow for the proper pricing in savings and credit markets.

These arguments definitely do contain elements of truth. For instance, it is definitely the case that escalating health and education costs have been an enormous burden on households (although to describe the current state of social policies in China as 'unravelling' dismisses very important efforts in the last decade to reform social security). It is also true that public pensions are scarce and paltry, especially outside of formal urban employment, and that average household income growth has been slower than GDP growth (although it has been growing at a pace that would make most other countries envious). And it is true that intensive efforts to industrialise in the context of enormous technological lags and structural transformations in the wider economy have led to various distortions, although this has been long recognised in the literature on late industrialisation. Indeed, it is the reason for industrial policy in the first place, including the skilful use of 'wrong' prices and state-controlled banks to guide and finance industrialisation efforts, without which growth would likely be much weaker. However, many of these aspects are not unlike the situation in the US over the last decade, during which working America experienced escalating health costs and stagnant wages despite massive direct and indirect subsidies to the corporate sector, including defence spending as an implicit tool of industrial policy. ${ }^{25}$ Notably, the combination of these aspects in the US led to a negative aggregate savings rate despite similar needs for precautionary saving among many households. ${ }^{26}$

Moreover, the arguments of Pettis (2009) and others above involve a blurring between a conception of savings as household savings (i.e. choices between consumption and saving out of total household income) and the residual concept of 'national savings' in national accounting (i.e. the difference between aggregate output and aggregate consumption). The latter conception assumes that aggregate savings equal aggregate investment whether by a neoclassical logic whereby savings drive investment, or else by

\footnotetext{
${ }^{25}$ For instance, see the very interesting discussion in Rutton (2006).

${ }^{26}$ For instance, Warren and Tyagi (2004) provide strong evidence that the erosion of living standards and rising levels of indebtedness among US middle class families since the 1970s have been due primarily to rising health, education and other related costs of expenditures necessary for family functioning. Yet, over the same period, household savings rates have fallen.
} 
a Keynesian logic whereby savings adjust to aggregate demand, which is driven by consumption and investment decisions. Notably, there is nothing implicit or explicit in national accounting that predisposes it to the neoclassical logic.

The distinction is important because there is, in fact, much contention around the caricature of Chinese household thrift. ${ }^{27}$ It is worthwhile to review at length a notable contribution by He and Cao (2007) that, although somewhat out-of-date, provides very useful insight into the nature of savings in China. They point out that the high levels of national savings in China are not explained by the household sector but by the government and corporate sectors. They clarify that the appearance of rising household savings rates is derived from household income surveys disaggregated by rural and urban areas. Nonetheless, rural household savings rates peaked in 1999 at 28.6 percent and then fell up to 2004, the most recent data which they cover. Urban household savings rates continued to increase up to 2004 but from a lower level, although the authors suggest that there have since been signs of a declining savings propensity among urban households as well. However, in combination, the average household savings rate had actually fallen 'dramatically' since the mid-1990s due to urbanisation, whereby a compositional shift from higher saving rural households to lower saving urban households resulted in a fall in the overall average savings rate. They therefore dismiss the 'precautionary savings hypothesis' to explain high savings rates in China. In particular, they note that aggregate household savings only accounted for a fraction of total national savings, falling from 52.3 percent of national savings in 1992 to 41.6 percent in 2001 (ibid:3-5). It has presumably fallen further since 2001 given that both the share of government consumption in total consumption and the share of gross capital formation in total GDP have continued to rise up to the most recent data in $2008 .^{28}$

Through a flow of funds framework, He and Cao explain that the high national savings rate is attributable to fast growth of savings in the non-financial corporate and government sectors. Increasing government savings of disposable income was a result of a combination of government institutional reform, including considerable austerity in government expenditure and employment, together with tax reform, which increased government revenue (ibid:5-6). The growth of the savings share of the non-financial corporate sector was due to growing profitability in the whole enterprise sector, not just state-owned enterprises (SOEs). Given that all of corporate disposable income is counted as savings in the national accounts, improved corporate profitability was reflected as a rising savings share even though the corporate share of total national disposable income did not increase much (ibid:6).

On the other hand, He and Cao note that insufficient consumption demand is also the result of a decreasing share of household to national disposable income since 1996. This point is similar to the argument of Pettis discussed above, although the detailed analysis by $\mathrm{He}$ and Cao reveals an implicit Keynesian slant that marks a crucial distinction. Notably, despite the high and increasing levels of savings in both the

\footnotetext{
${ }^{27}$ Krugman (2009a) remarks that this caricature is reinforced by Chinese leaders themselves, noting that Zhou Xiaochuan, the governor of China's central bank, seemed to assert in a speech 'that China's extremely high savings rate is immutable, a result of Confucianism, which values "anti-extravagance."” However, it is not unusual for political elites to adopt, internalise and propagate ideational caricatures in this way. Arguably, these processes are crucial to understand the manner by which neoliberal ideologies were adopted and disseminated by Latin American and African elites.

${ }^{28}$ See CSY (2009: Table 2-17 and 2-18).
} 
government and non-financial corporate sectors, such savings were insufficient to meet investment demand, which in turn was covered through various forms of borrowing. An increasing share of government expenditure was being used as direct investment in fixed assets and as indirect investment via capital transfers to SOEs, which the central government has been increasingly required to finance by issuing large amounts of government bonds due to insufficient government savings. ${ }^{29}$ Similarly, non-financial corporate savings (i.e. earnings) covered only about half of that sector's investment needs, albeit the gap had been shrinking slightly up to 2001 (their most recent data on this issue), reflecting the greater role of retained earnings in financing investment. Bank lending was the major source of financing to cover the gap, ${ }^{30}$ although other sources included portfolio finance and an increasing share of financing from abroad, the latter reaching 39 percent of bank loans already by 2001, up from 22 percent in 1992 (ibid:1011). In other words, the appearance of rising national savings rates up to this time in large part seems to reflect monetary expansion, credit creation, increasing levels of foreign financing, and increasing levels of reinvested corporate earnings, all in response to investment demand. Some of these factors partly concur with Pettis' argument that household depositors have been financing corporate debtors, although on this specific point Pettis ignores the role of monetary policy and bank lending in amplifying this mechanism of transmission, and the role of foreign investment in further augmenting the available liquidity.

This would also help to explain the falling share of household disposable income in national income despite very high rates of growth in such household incomes that are the envy of most developing countries. It is in this sense that the high residual category of national savings should not be conflated with a notion of repressed consumption or savings-led investment but, rather, as an attribute of the speed by which China has been catching-up. Indeed, through an international comparison of aggregate savings rates, He and Cao demonstrate that, if the depreciation method adopted in China and South Korea were used for Japan, ${ }^{31}$ China's saving rate in the 1990s and early 2000s was at about the same level as that of the Japanese and South Korean economic take-offs, except in 2000 when the Chinese national saving rate was slightly higher (as would also be the case for the period in the later 2000s, which they did not cover). Citing Hayashi (1989), they note that if similar adjustments are made, 'the Japanese national saving rate was higher than that of the United States only during the catching-up period...' and approached the US level since the 1980s. 'In other words, [...] the current national saving rate in China... is reasonable if considering the fast development stage in which China stands currently' (ibid:9). While they recommend a variety of government-directed redistributive policies and further reform in the domestic financial sector to deal with the resultant imbalances,

\footnotetext{
${ }^{29} \mathrm{He}$ and Cao note that this reflects the direct involvement of the government in more and more economic activities. Also see the very interesting discussion of bond issuance in Sun (2009). This point also implies that the high savings rates in this sector is, in part, an artefact of accounting. For instance, if the capital investments and transfers by the government would be included as part of government consumption given that they are expenditures, there would be effectively no savings in this sector. In other words, the appearance of greater government savings actually represents a shift in the composition of government deficit spending towards greater capital investments and transfers. This is discussed further below.

30 Again, see Sun (2009) on monetary policy and the banking sector in China.

31 The depreciation method in China is based on historical costs (He and Cao 2007:9).
} 
currency appreciation and international financial liberalisation are absent from their recommendations, in contrast to Pettis and Wolf, as discussed above.

The issue of currency revaluation reveals another fallacy of the savings-supplyside analysis of the Chinese growth experience. Namely, it is not at all clear whether revaluation would have any impact on China's external surpluses, nor is it clear whether the Chinese renminbi is even undervalued in the first place. Among the substantial debate on this issue, ${ }^{32}$ a notable contribution was made by Lau and Stiglitz (2005) during the peak of the campaign for China to revalue in 2005. At that time, they argued that 'there is currently no credible evidence that the renminbi is significantly undervalued, and an adjustment in its exchange rate at this time is neither warranted nor in the best interests of China or global economic stability.' Among their various reasons, they noted that China's multilateral trade surplus was only in slight surplus. They argued that currency appreciation would not be likely to reduce significantly the US balance of payments deficit with China given the high import content of China's exports to the US (which they suggested is as high as 70-80 percent). This would counterattack the price impact of appreciation because higher prices for exports would be offset by lower prices for the imported inputs for these exports. On the other hand, they note that revaluation would place an immediate downward pressure on Chinese agricultural prices and thus on rural incomes. This is a point that Pettis (2009) ignores in his assertion that appreciation would improve incomes by lowering prices for imported consumption goods, which is an argument that refers mostly to consumption by urban households and assumes that much of their consumption is imported, whereas 40 percent of China's labour force was still employed (mostly self-employed) in agriculture as of 2008 (CSY 2009: Table 4-3). A related issue not mentioned by Lau and Stiglitz is the fact that export-oriented enterprises would likely respond to whatever loss of competitivity that appreciation would entail by attempting to lower unit-costs through one of two mechanisms; either by repressing wage rates (or intensifying work at the same wage rates) and/or raising labour productivity. Indeed, elements of both tendencies have been observed since 2005 and both would have had the effect of exacerbating the lag between household disposable income growth and national income growth by raising the share of enterprise earnings vis a vis wages.

Despite these arguments against appreciation, the Chinese government nonetheless allowed the renminbi to appreciate against the US dollar by about 20 percent from July 2005 to July 2008. Simultaneously and in apparent contradiction, the trade surplus in goods exploded from around 3 percent of GDP in 2004 to a peak of over 9 percent in $2007 .{ }^{33}$ More specifically, the value of the trade surplus with the US more than

\footnotetext{
${ }^{32}$ A consistently adamant proponent of the argument that the reminbi is overvalued and that China is a currency manipulator is Goldstein (e.g. 2003; 2004; 2006) and Goldstein and Lardy (2006), both from the Peterson Institute mentioned in the second section above. A more balanced approach is provided by Frankel and Wei (2007). For more critical perspectives, see Yang and Dou (2004), Funke and Rahn (2005), Zhang and Fung (2006), Groenewold and He (2007) and Wang et al (2007).

${ }^{33}$ The balances are calculated from balance of payments data from various China Statistical Yearbooks. The services balance remained mildly negative throughout this period. The income account turned positive for the first time in 2005 and was approaching one percent of GDP in 2008, while current transfers remained at just above one percent of GDP since 2003. Aggregated, the current account reached 11 percent of GDP in 2007. The capital account surplus amounted to an additional 2.17 percent and errors and omissions 0.48 percent, leading to an accumulation of reserves equivalent to 13.65 percent of GDP in 2007. See Fischer (2009c) for further details.
} 
doubled between 2004 and 2007, increasing from about 4 percent to 5 percent of nominal Chinese GDP converted into US dollars at market exchange rates, i.e. even after accounting for the effect of revaluation on this nominal calculation. ${ }^{34}$ This simple observation seems ignored by the proponents of further currency appreciation now. It suggests that the external imbalances have borne little relation to the exact relative valuation of the Chinese currency but, rather, to underlying structural changes in the organisation of international trade and production.

Even if we reject the notion that excess savings have been driving these surpluses, an argument could still be made, as does Pettis above, that the excess output has been caused by artificially-high levels of investment encouraged and subsidised by government industrial policies intent on 'turbo-charging economic growth.' Hence, from this logic, it could be argued that excess output has been driving external imbalances, as if China's exports were acting as a 'vent for surplus,' alluding to Adam Smith's conception of the role of international trade. However, this obviously begs the question of what is allowing for the consumption of such output surpluses. In other words, what are the international factors that enable the government to follow such investment strategies in the first place? After all, at the end of the 1990s and in the wake of the East Asia crisis, the Chinese economy was facing serious problems with overproduction in many sectors, as well as generalised price deflation in the economy, particularly for agricultural and manufactured goods. From the vantage point of the time, it was not obvious whether the government would be able to continue an investment-driven strategy. As reasoned by $\mathrm{Hu}$ Angang (2000); 'We will see what is going to happen after the WTO rules take effect but for the time being it is difficult to know what will happen in those sectors.'

Many economic commentators in the US have suggested that the US consumption of this surplus was more or less induced by the imbalance, given the responsiveness and absorptive capacity of its mature free market economy. Hence, the reasoning that overproduction caused trade and foreign exchange surpluses, which in turn caused the credit bubble. The alternative hypothesis is that financially-lubricated corporate restructuring and expansion in the US and other Northern economies drove Asian surpluses. Lau and Stiglitz blame US government deficits for driving imbalances. In order to analyse this question, it is useful to examine the sequencing of Chinese current account surpluses and US current account deficits, presented in Figure 1 below. The US deficits and Chinese reserves are presented with reversed signs in order to more effectively evaluate the evolution of this bilateral comparison. The values are in current US dollars as this best represents the respective monetary weights of the imbalances in the international economy, particularly in comparison to each other.

Through this simple comparison, it is quite clear that the argument that Chinese surpluses have been fuelling the credit bubble in the US equates to placing the cart in front of the donkey. China's current account surplus shrank from a brief East Asia crisis high of 40 billion USD in 1997 to 17.4 billion USD in 2001 (1.3 percent of its GDP), while the US current account deficit simultaneously fell from -141 billion USD to -398 billion USD. The bursting of the dotcom bubble in 2000 and the ensuing recession in the US caused a slight correction to this trend in 2001, but thereafter the US current account deficit continued its precipitous decline, whereas the Chinese current account only started

\footnotetext{
${ }^{34}$ Note that there is some discrepancy between these trade data and the previous balance of payments data above, possibly because Hong Kong is excluded from the former whereas it might not be in the latter.
} 
to increase at a comparable pace after 2004 (in terms of year-on-year increase in nominal value, not in terms of pace of change). Up to 2004, China's surplus had increased only gradually to 69 billion USD by 2004, whereas the US current account deficit had fallen to -631 billion USD. In comparison to 1997, the Chinese surplus had not even doubled by 2004, whereas the US deficit had increased 4.5 times. The nominal increment in surplus for China was only 28.7 billion USD between these years, whereas the US deficit had increased by 490.4 billion. In this light, the argument that the reduction in the US fiscal deficit as a proportion of GDP in 2003 caused an expansion in the private sector deficit due to the necessity to absorb global imbalances (primarily those from China) appears particularly specious, at least in the case of China. It is only from 2005 onwards that the current account surplus of China started to explode at a pace comparable to the US freefall into deficit that had been well in course since the East Asian crisis.

\section{Figure 1: US current account deficit (reversed) and China current account surplus}

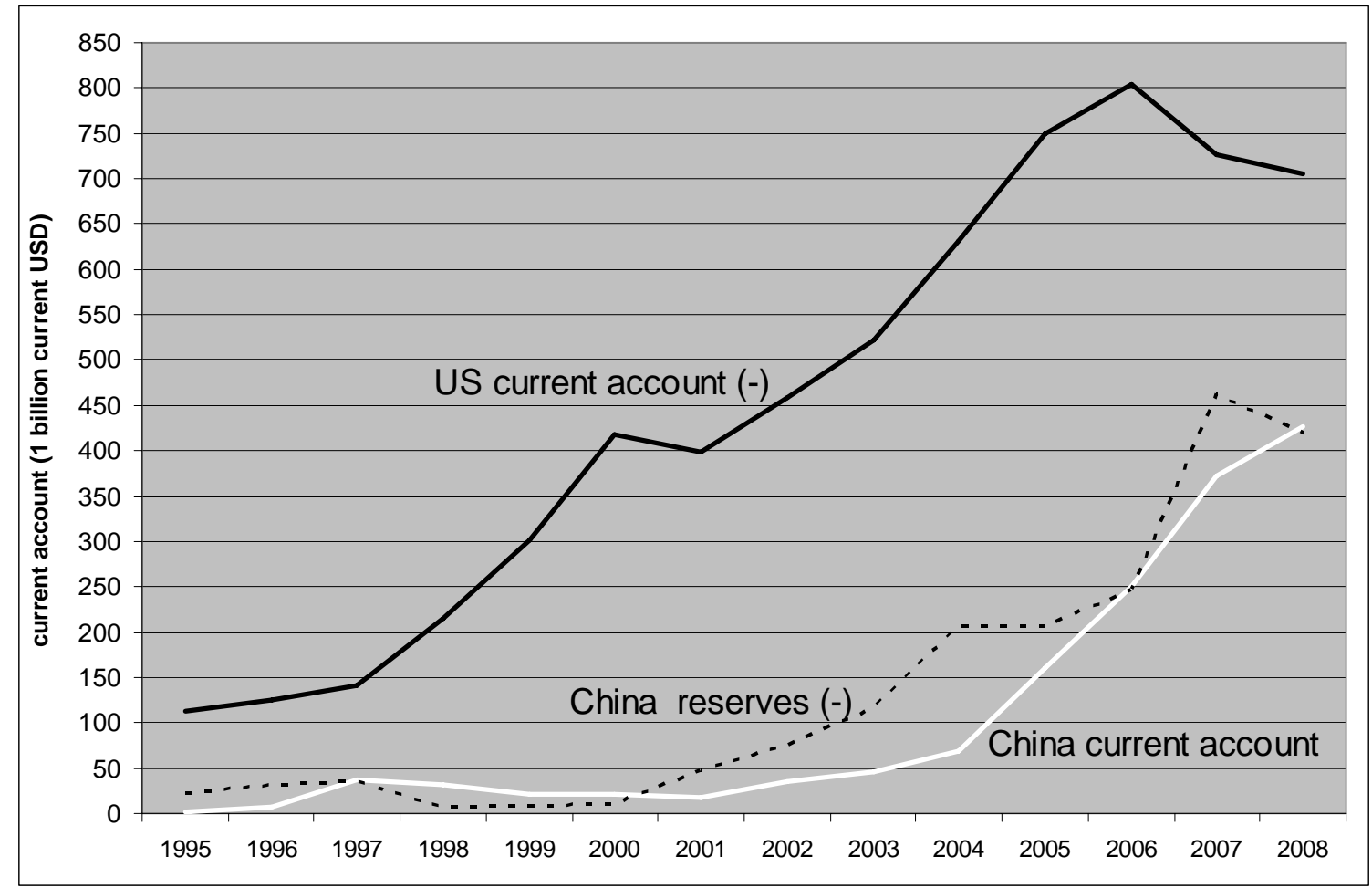

Source: Chinese data from CSY (2009: Table 2-34) and US data from the IMF International Financial Statistics database, accessed on 27 October 2009. Note that the Chinese data is identical in both sources.

The story might appear somewhat differently if examined exclusively in terms of the bilateral deficit between the US and China, as is the obsession with most US commentators. This bilateral deficit did accelerate in 2001 and increased more or less continuously up until 2008, as did the surplus with Europe. ${ }^{35}$ Indeed, the surplus with Europe grew even faster; it started from almost zero in 2001 and actually surpassed the surplus with the US in 2008 for the first time (exports to Europe were actually greater than exports to the US, but so were imports from Europe). However, these observations

\footnotetext{
${ }^{35}$ Data on the trade accounts in this and the following paragraph are calculated from data compiled from CSY (2009: Table 17-8) and equivalent tables in earlier statistical yearbooks.
} 
need to be qualified by the equally dramatic changes that were occurring on the other side of trade balance, i.e. the equally dramatic descent into deficit with the rest of Asia (mostly East and Southeast Asia), from a slight surplus in 1999 and a slight deficit in 2001, to a sudden increase in the trade deficit to about 74 billion USD by 2004, almost equal to the surplus with the US of 81 billion in the same year. This descent stalled from 2005 onwards, not because of a slow down in trade but because China's exports to Asia started to catch-up with imports from Asia, which again is counterintuitive given the revaluation of the yuan from 2005 onwards. In any case, the stalling of the deficit with Asia explains the sharp rise in the overall trade balance from that year onwards given that the surpluses with the US and Europe continued to rise.

The picture is even more dramatic from the viewpoint of gross import and export volumes with Asia, which exceeded even the combination of trade volumes with the US and Europe. For instance, China's imports from Asia increased from 147 billion USD in 2001 to 620 billion USD by 2007 (over half of total imports), while its exports to the US increased from 52 billion USD to 252 billion USD and its exports to Europe increased from 49 billion USD to 288 billion USD. In other words, China's trade surplus in 2007 was equivalent to about 23 percent of the combined volume of its imports from Asia and exports to the US and Europe, or else 12 percent of its total import and export volume worldwide. While the latter measure had increased since the early 2000s, it was actually less than in 1997 and 1998, when China's balancing was acclaimed by many to have played an important stabilising role in the East Asia crisis. From this perspective, it is also clear that, although very large in nominal terms, the recent trade surpluses have been generated through phenomenal (and phenomenally increasing) volumes of turn-over, particularly in the processing trade between East Asia, the US and Europe.

Returning to the overall picture presented in Table 1 above, the trend of rising imbalances on the side of China also appeared sooner in terms of reserve accumulation. Reserves started to increase in 2001, although still slower than the increasing current account deficits of the US. Notably, this was because of a huge surge of capital inflows into China between 2001 and 2005. These would have been related, in large part, to the centrifugal capital outflows from the US during the recession in 2001 combined with increased net inflows of FDI parallel to China joining the WTO in the same year. Then, much of the inflows were related to speculation on renminbi revaluation up to 2005 together with further FDI. In other words, these capital flows were a reflection of financialisation in the US rather than a cause of it. Moreover, they actually represent the effective subsidisation of US financial capital by China given that, as noted by Zheng and Yi (2007:21-22), China was paying out much higher rates of return on inward foreign investment and on their related sterilisation operations in China than they were earning from the resultant sterilised foreign currency largely held in US Treasury securities. In any case, it can hardly be said that reserves accumulated by China through its sterilisation of capital inflows subsequently contributed to the credit bubble in the US given that much of these inflows derived from credit expansion in the US in the first place (and from credit expansion in supporting financial centres such as the UK and its offshore laundering subsidiaries). The fact that the surge on the capital account preceded the surge on the current account by about three to four years suggests that the latter was due to international restructurings of production and distribution that were being led by the former, as noted above in terms of the phenomenally increasing trade flows. 
While more detailed analysis of causality is required, ${ }^{36}$ there is a strong case to be made that the Chinese current account surpluses were responding to imbalances in the US. Indeed, the US credit bubble had already been well in progress by 2005, when the Chinese current account surplus started to explode. The US current account deficit then hit its trough (in terms of current nominal value) in 2006, at the peak of the credit bubble in the US. As mentioned above, the Chinese trade surplus in goods hit its peak as a proportion of GDP in 2007, at the outset of the US credit crisis, after which it has since fallen. While the Chinese current account surplus has continued to increase in nominal value, in 2008 it still remained about 280 billion USD less than the US current account deficit in the same year.

These dynamics are even clearer in Figure 2 below, which shows the year-on-year increments to the current account surplus/deficit of China and the US over the same period, calculated from the previous data and expressed in current US dollars. This comparison might be the basis of arguing that, regardless of the low starting position of China's current account in 2001, what matters for fuelling the credit bubble in the US are the yearly increments in the surplus, not the absolute size of the surplus, given that a Chinese surplus that increases faster than the US deficit (in terms of absolute nominal value) might counteract the potential for monetary dampening generated by a shrinking US deficit. This argument is obviously tenuous given that surpluses and reserves in each year are themselves increments to previously accumulated reserves, but the argument is nonetheless worth considering in order to give the full benefit of doubt to the savings supply-side arguments of Wolf and others.

\section{Figure 2: yearly increments in current account deficit/surplus, US and China}

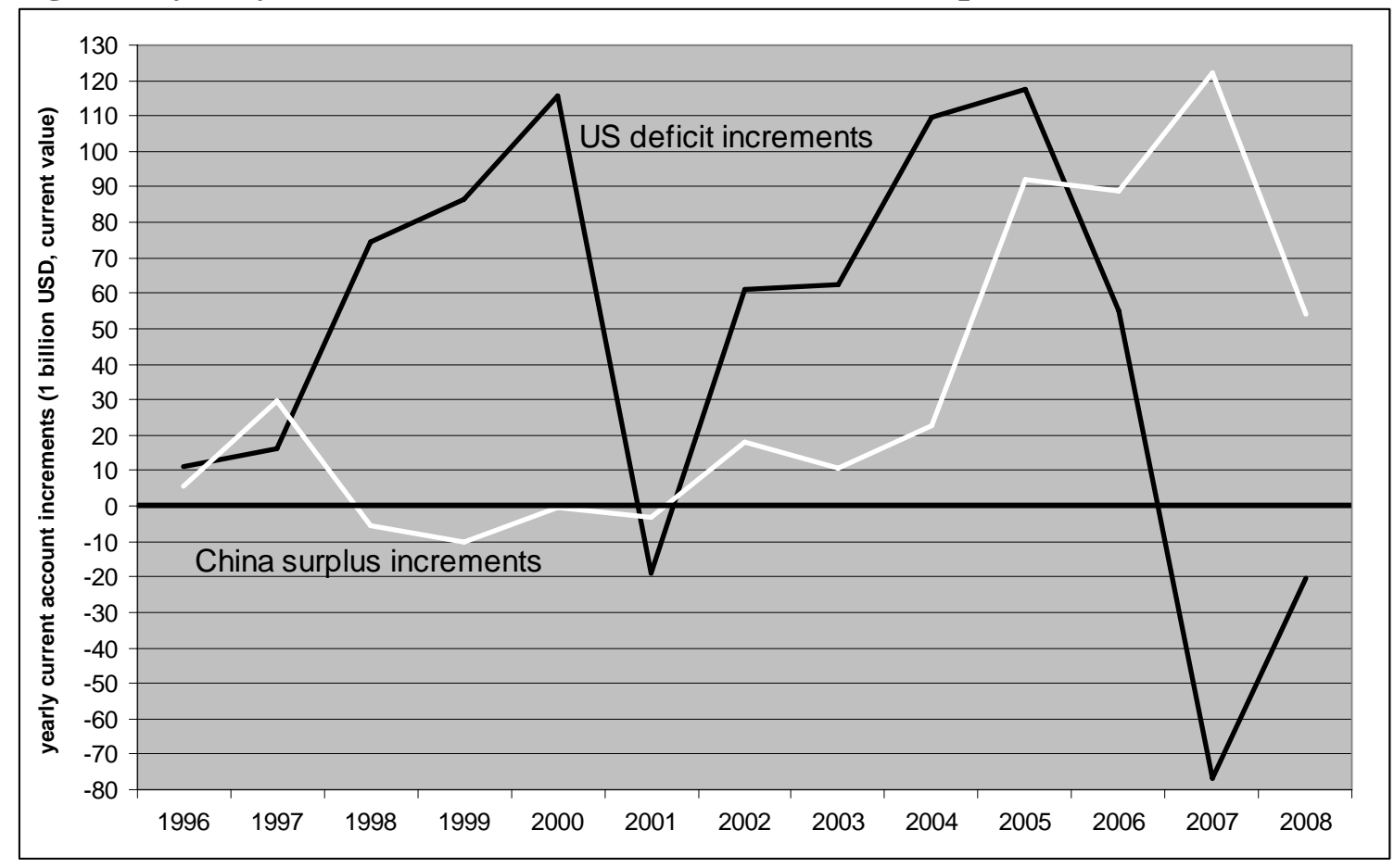

\footnotetext{
${ }^{36}$ See some preliminary work in Fischer (2009c).
} 
However, even if the potential for this argument were pushed, it would only hold from 2006 onwards. In terms of nominal yearly increments, the US deficit was falling much faster than the Chinese surplus was increasing from 1998-2000 and again from 2002-2005. It is only in 2006 that this argument might hold, although by this point the credit bubble in the US had already reached its zenith and was starting to wane, mutating into volatile international activities such as carry trades and other speculative pursuits by hedge funds and related financial institutional innovations (see UNCTAD 2007:15-22). Notably, the only times that this argument might hold is when the US was in recession. Ironically, according to this frame of analysis, Chinese surpluses play a counter-cyclical rather than pro-cyclical role in the US economy. From this perspective, blaming China for the credit crisis is equivalent to blaming the fire truck for the fire.

The key question in this analysis of sequencing regards the causes of the sudden emergence of China as mercantilist tour de force since 2001. Notably, up to the late 1990s, China's current and capital accounts were much more typical of a 'late late' peripheral industrialiser, in the sense that growth spurts usually ended in current account deficits, subsequently requiring austerity to correct. China's escape from this classic predicament of peripheral late industrialisers appears intimately related to the systemic rerouting of East Asian centred international production networks through China that followed the East Asian crisis in 1997-98. As discussed above, this can be inferred through a regionally disaggregated examination of its trade balances, which reveals that the pattern by which China has built very large trade surpluses with the US and Europe parallel to large trade deficits with East and Southeast Asia only emerging since the East Asia crisis. ${ }^{37}$

A growing body of literature on multinational corporations (MNCs) in Asia confirms this observation, ${ }^{38}$ providing strong evidence of China's subordinate third or even fourth-tier position within these production networks. Athukorala and Yamashita (2009) in particular argue that the growing trade deficit between China and the US ...has been underpinned by China's emergence as the main point of final assembly in Asian production networks, based on its ample supply of labor, and moves taken by US firms to supply high-end parts and components from their Asian bases to China. In sum, the deficit is, to a large extent, a structural phenomenon driven by the process of global production sharing (ibid: 54-55).

Hence, they argue that, instead of China becoming an advanced-technology superpower based on its structural shift away from traditional labour-intensive products and towards ICT products, 'closer examination of the data suggests... the rapid consolidation in China's final-assembly stages of East Asian-centered global production networks of these products' (ibid:48). Yao (2009) similarly argues in a strong critique of Rodrik (2006) that 'it is tempting to think that the export surge of [the sector of machinery and electrical machinery and parts] represents technological upgrading in Chinese exports... All indications suggest that the rise of the sector in China's foreign trade be closely associated with its processing trade regime and foreign outsourcing to China.' (Yao 2009:

\footnotetext{
${ }^{37}$ See Fischer (2009c) for analysis of these data, as well as Athukorala and Yamashita (2009). Also see Fischer (2009b) for a more general discussion of this predicament of post-war late industrialisation.

${ }^{38}$ In particular, see excellent contributions by Athukorala (2005, 2007, 2009), Li et al (2007), Sung (2007), Athukorala and Yamashita (2009) and Yao (2009). Also see Bergsten et al (2006).
} 
63). These arguments confer with the previous observation from He and Cao (2007) that finance from abroad has been quickly rising in prominence in the late 1990s and 2000s as a source of funding for non-financial corporations, increasingly complementing government funding and bank loans.

In other words, arguments for revaluation of the renminbi as part of the solution for global imbalances avoid this emerging role of China as mass processor in the final assembly of goods destined for US and European consumption through networks heavily and increasingly dominated by Northern MNC production and distribution networks. They also avoid the parallel processes of financialisation in the US and Europe that fuelled not only consumption in these final trade destinations but also Northern consolidation of control over these production networks in the 2000s. This essential missing link leads to a completely different line of analysis regarding the significance of the China's imbalances and, more importantly, who effectively owns and controls the wealth that they represent. For instance, Zheng and Yi (2007: 19) note that

...China's growing foreign exchange reserves do not imply wealth that is disposable at any time, but rather a sizeable indirect debt. In 2005, only half of China's accumulated foreign exchange reserves were consistent with its wealth, which allowed Beijing to fulfill international payment obligations. The remaining capital inflows (FDI and short-term foreign borrowings) could be interpreted as implied debts... that China would have to pay back eventually.

Similarly, in communications with Jan Kregel, he indicated that from information presented to the recent meetings of the Commission of Experts of the President of the UN General Assembly on Reforms of the International Monetary and Financial System, it was quite clear that the external figures on the foreign exchange holdings of China are meaningless for most purposes, especially since a large proportion are apparently nonrepatriated profits of joint ventures with foreign multinationals. ${ }^{39}$

Writing more broadly on the role of late industrialising developing countries in international imbalances, Kregel (2008) poignantly reflects that '....it is possible that a deterioration of the recorded US trade balance could be reflected in the increased profitability observed in the past ten years for US companies operating in the global market' (ibid:28). He further remarks that

....as a result of the increased influence of capital flows on trade and the geographical dispersion of intermediate stages of production, the current account in many countries is increasingly determined by factor incomes representing interest, profits, and dividends on foreign production, and borrowing and lending. All of these capital factor incomes are fully recorded by national origin, while goods and factor services balances are no longer representative of real underlying flows. Paradoxically, in the modern world, capital flows may no longer represent transfer of resources or the financing of productive activity, and goods flows may no longer represent production of final goods for import or export (ibid:28)

He concludes his article with the observation that '...it becomes clear that any analysis of the impact of the international imbalances on economic performance of countries and on

${ }^{39}$ Email communication with Jan Kregel, 22 August 2009. 
the performance of currencies should take into account the fact that we do not have a good idea of the dimension of the problem' (ibid:31). Athukorala and Yamashita draw a similar conclusion, noting that 'trade flow analysis based on data coming from a reporting system designed at a time when countries were trading only in final goods naturally distorts values of exports and imports, leading to a falsification of current account imbalances' (2009:40). ${ }^{40}$

It is vital to view the current debates regarding global imbalances in this light. The presumption that China is in a position of strength and should thus move from its defensive strategy of reserve accumulation to one that adopts a much more pro-active position of mediating imbalances in the international monetary and trading system through greater openness and less interference in its exchange rate is one that treats China as if it were one of the central powers behind the expansion and regulation of this monetary and trading system. A false evaluation of such strength could have dramatic implications for China, particularly if the proposed strategies of currency and financial liberalisation would result in accentuating vulnerability to volatile capital flows in the near-future reverberations of the current crisis. This concern is all the more important given that, despite the attention focused on China's reserves, these have been in fact dwarfed by the volumes of international liquidity that contributed to the build up to the current crisis and that were largely generated by Northern financial systems. They are also dwarfed by the massive volumes of liquidity that were suddenly created by Northern central banks in response to the crisis and by the volumes currently involved in the enormous resurgence of carry trading that has resulted from such central bank interventions. In the wake of such huge surges of international liquidity and the possible inflationary consequences, it is plausible that China's own foreign exchange reserves today could be quickly eroded in the medium term. From this perspective, the concern of the Chinese leadership with regard to the current situation would seem to be based not so much on maintaining the value of the country's saved assets stored largely in the US, as superficially suggested by many western commentators, but much more pertinently, on avoiding the predicament of Latin America and East Asia before it. In other words, China's leaders are probably quite rightly concerned with falling back into the stringent external constraints typical of post-war late-late industrialisers, from which China only very recently escaped on the basis of riding a wave of financialisation and industrial restructuring emanating from the west.

\section{Conclusion}

This paper focused on ideological reconstitutions in the face of financial crises past and present. First, several contemporaneous debates were revisited concerning the lead up to the 1982 debt crisis, which marked a decisive turning point in US global hegemonic revival. While this crisis was fundamentally rooted in disequilibria related to the breakdown of the Bretton Woods system, it was recast as a problem of surpluses emerging from oil price shocks in the 1970s and subsequent excessive and irresponsible borrowing by developing countries ready to recycle these surpluses. This recasting created the ideological justification in support of policies that shifted most of the burden of adjustment from northern financial sectors to developing country governments. The emergent monetarist consensus of the 1980s thereby managed to recast its own policy

\footnotetext{
${ }^{40}$ They cite Jones and Kierzkowski (2001) on this point.
} 
failures in dealing with the debt crisis into ideological triumph. To borrow the words of Carlos Diaz-Alejandro (1984:335), it did this by conveniently blaming its far-fromvirtuous victims, and, as is typical in contemporary aid debates, by tautologically focusing on the outcomes of crisis as if these were the principle causes of crisis. This instant revisionism in the face of systemic crisis was so successful that the resulting narrative is rarely challenged or questioned in the mainstream development studies literature today. Indeed, it is often noted that the current crisis is the first major crisis since the 1930s to have emerged from the centre rather than from the peripheries, even though the 1982 debt crisis was arguably also an outcome of building crises and disequilibria emanating from the centre.

Second, the paper examined how the crisis today has been quickly framed by leading public economists, usually with platitudinous references to Keynes, as a problem of excess savings in the rising Eastern peripheries. Chinese external surpluses in particular receive the brunt of blame as one of the primary sources of excess savings. As a logical corollary, it is argued that China must carry its share of the resultant costs of adjustment, not only by contributing to the bail out but also through medium-term structural adjustments aimed at correcting its surplus position, principally by allowing its currency to appreciate and by reforming itself through financial liberalisation and other market reforms, thereby freeing up the repressed consumption of its citizens.

Third, the paper questions these narratives and proposes an alternative interpretation of global imbalances from the perspective of a correct understanding of Keynes. From this Keynesian perspective, the appropriate logic would be that US aggregate demand drives US external imbalances, which in turn drive the imbalances of those economies oriented towards servicing US demand, primarily through investment demand in those economies, to which aggregate monetary savings adjust. Placing this in the context of China, China's investment rates are not high because the Chinese save a lot. Rather, China's aggregate monetary savings (including government deficit spending, credit from its banking system, retained and reinvested corporate earnings, and finance from abroad) are high because of high rates of investment, which are in large part a response to aggregate demand from the US and Europe, among other factors. China's growing external surpluses and foreign exchange reserves are outcomes of these processes rather than causes. In other words, another phase of rampant financialisation in the centre drives global imbalances in the peripheries, similar to the conditions surrounding the break down of the Bretton Woods system in the 1970s.

There is a strong case to make that this Keynesian interpretation fits the historical stylised facts much better than the dominant narrative. This can be construed from the futile efforts of Chinese authorities to lower dependence on investment over the past decade, from the characteristics of high national savings rates in China, and through an assessment of the question of whether the Chinese currency is in fact undervalued. Finally, through an analysis of the sequencing of US current account deficits and Chinese current account surpluses, there is a strong case to be made that the Chinese current account surpluses have been responding to imbalances in the US and have been intimately related to the systemic rerouting of East Asian centred international production networks through China that followed the East Asian crisis in 1997-98. Arguments for revaluation of the Chinese renminbi more or less avoid the implications of this emerging role of China as subordinate mass processor in the final assembly of goods destined for 
US and European consumption through networks heavily and increasingly dominated by Northern MNC production and distribution networks.

As in the past, the danger with the dominant narrative is that it facilitates an ideological reframing that justifies shifting the burden of adjustment away from Northern financial sectors and towards the most obvious Southern scapegoats within the international economic order. In this manner, an ideological reconstitution is taking place before our very eyes even in the midst of the ongoing crisis and ironically in the name of Keynes, albeit in a way that severely distorts Keynes' most essential messages. Moreover, this narrative has captured the imagination of many on the political left as well as right in their attempts to explain the current crisis, hence the potential for ideological reconstitution that cuts across traditional political positions in the North and taps into important currents of popular public perception and opinion. These processes of paradigm maintenance need to be urgently addressed if the current crisis is to be leveraged for a return to a more progressive, inclusive and developmental policy paradigm in both North and South. Failing this, current orthodoxies risk being reconstituted or even reinforced. Through a sense of complacency that the 'consensus has been shattered' - a conventional wisdom common among both Left and Right - we risk finding ourselves soon entering a new round of radical systemic adjustments producing development debacles similar to those of early 1980s.

In other words, the currently emergent narratives of global imbalances directed at China can be understood as potentially playing the same role that neoliberal ideologies played in the 1980s and 1990s, legitimising strategies from the centre that are ultimately bent on discipline and subordination, whether devised or emanating from impulsive protective responses to crisis. The advocated strategies are unlikely to solve the issues that they purport to address, but in the havoc potentially created they could enact a reconsolidation of US economic hegemony, albeit with dubious implications for publics in both China and the US. For, if we see US-China trade in terms of bilateral arms-length transactions of finished goods as per conventional conceptions of trade in economic theory, it is true that China cannot continue to rely on over-indebted US consumers to continue to consume its surpluses. But if we see the organisation of this trade not in terms of countries but in terms of corporations and their networks controlling wealth, then yes, the imbalances can and probably will continue because they are not expressions of market outcomes but of structures of power. The narratives of global imbalances must therefore be seen as the emerging ideological discourses of such power, whether or not their proponents are aware of this implication.

\section{References}

Arrighi, Giovanni (2002), ‘The African Crisis: World Systemic and Regional Aspects', New Left Review 15: 5-36.

(2003), 'The Social and Political Economy of Global Turbulence’, New Left Review 20: 5-71.

Athukorala, Prema-chandra (2005). 'Product Fragmentation and Trade Patterns in East Asia.' Asian Economic Papers 4(3): 1-28.

----- (2007). Multinational Enterprises in Asian Development. Cheltenham, UK: Edward Elgar.

----- (2009). 'The Rise of China and East Asian Export Performance: is the crowding-out fear warranted?’ World Economy 32(2): 234-66. 
Athukorala, Prema-chandra, and Nobuaki Yamashita (2009). 'Global Production Sharing and SinoUS Trade Relations.' China and World Economy 17(3): 39-56.

Bergsten, C. Fred, Bates Gill, Nicolas R. Lardy and Derek Mitchell (2006). China: the Balance Sheet. New York: Public Affairs.

Brenner, Robert, 'The Economics of Global Turbulence: A Special Report on the World Economy’, New Left Review I/229 (Special Issue).

(CSY) National Bureau of Statistics (2009). China Statistical Yearbook 2009. Beijing: China Statistical Press.

D’Arista, Jane (2009). 'The Evolving International Monetary System.' Cambridge Journal of Economics 33: 633-652.

Diaz-Alejandro, Carlos F. (1984), 'Latin American debt: I don't think we are in Kansas any more', Brookings Papers on Economic Activity, 2: 335-390.

Dymski, Gary (2008). 'Is Financial Governance Feasible in the Neoliberal Era? Reflections on the Post-War Evolution of Financial Risk.' Mimeo, 9 June 2008.

----- (2009). 'From Financial Exploitation to Global Banking Instability: Two Overlooked Roots of the Subprime Crisis.' Mimeo, 26 July 2009, forthcoming in Martijn Konings (ed.), Beyond the Subprime Headlines: Critical Perspectives on the Financial Crisis. London: Verso.

Fischer, Andrew M. (2005), State Growth and Social Exclusion in Tibet: Challenges of Recent Economic Growth. Copenhagen: Nordic Institute of Asian Studies Press.

----- (2007), 'A Theory of Polarisation, Exclusion and Conflict within Disempowered Development: the case of contemporary Tibet in China,' PhD thesis, London School of Economics.

----- (2009a), 'Educating for Exclusion in Western China: structural and institutional foundations of conflict in the Tibetan areas of Qinghai', CRISE Working Paper no. 69, Oxford: Centre for Research on Inequality, Security and Ethnicity, Queen Elizabeth House, Oxford University, July.

----- (2009b), 'Putting Aid in its Place: insights from early structuralists on aid and balance of payments and lessons for contemporary aid debates,' Journal of International Development 21: 856-867.

----- (2009c), 'Is China Turning Latin? China’s balancing act between power and dependence.' Forthcoming working paper.

Frankel, J.A. \& Wei, S. (2007). "Assessing China’s Exchange Rate Regime ". NBER Working Papers 13100, National Bureau of Economic Research.

Frieden, Jeffry (1981), 'Third World Indebted Industrialization: International Finance and State Capitalism in Mexico, Brazil, Algeria, and South Korea', International Organization 35(3): 407-431.

Funke, M. \& Rahn, J. (2005). 'Just how undervalued is the Chinese renminbi?' World Economy. pp. 465-631.

Goldstein, Morris (2003). 'China's exchange rate regime.' Testimony before Subcommittee on Domestic and International Monetary Policy, Trade, and Technology. Committee on Financial Services. US House of Representatives, 1 October.

----- (2004). ‘Adjusting China’s Exchange Rate Policies.’ PIIE Working Paper 04-1, Peterson Institute for International Economics, Washington DC, June.

----- (2006). "RMB Controversies” Cato Journal, vol. 26, no. 2.

Goldstein, Morris and Nicholas R. Lardy (2005). 'China's Role in the Revived Bretton Woods System: A Case of Mistaken Identity.’ PIIE Working Paper 05-2, Peterson Institute for International Economics, Washington DC, March.

----- (2009). 'The Future of China's Exchange Rate Policy.' Policy Analyses in International Economics 87. Peterson Institute for International Economics. 
Groenewold, N. \& He, L. (2007). “The US-China trade imbalance: Will revaluing the RMB help (much)?” Economics Letters 96 : 127-132.

Guha, Krishna (2009). 'Bernanke warns on imbalance risks.' Financial Times, 19 October.

Hayashi, Fumio (1989). 'Is Japan's saving rate high?’ Federal Reserve Bank of Minneapolis Quarterly Review 13(2):1-9.

He, Xinhua, and Yongfu Cao (2007). 'Understanding High Saving Rate in China.' China and World Economy 15(1):1-13.

$\mathrm{Hu}$, Angang (2000). 'On China Reforms and the Go-West Policy (an interview with Hu Angang by Laurent Malvezin).' China Sustainable Industrial Development Network, last accessed on $30 \quad$ October 2009 at http://www.csid.com.cn/Forum/ScholarAInfo.asp?LanType=1\&SAId=19

Hussain, Athar (2002). 'Poverty Profile and Social Security in China: Final Report.' London, Asia Research Centre, London School of Economics.

----- (2003). 'Urban Poverty in China: Measurement, Patterns and Policies', InFocus Programme on Socio-Economic Security, Geneva: International Labour Office.

Hutton, Will (2007). The Writing on the Wall: China and the West in the 21st Century. London: Little, Brown.

Jones, Ronals W., and Henryk Kierzkowski (2001). 'A Framework for Fragmentation,' in Seven Arndt and Henryk Kierzkowski (eds.), Fragmentation: New Production Patterns in the World Economy. New York: Oxford University Press, pp.17-34.

Kregel, Jan (2008). 'Financial Flows and International Imbalances - The Role of Catching-up by Late Industrializing Developing Countries.' Working Paper No. 528, Levy Economics Institute of Bard College, Annandale-on-Hudson, February.

Krugman, Paul (2009a). 'China’s dollar trap.’ New York Times, 2 April.

---- (2009b). 'China and the liquidity trap.' New York Times, 15 May.

----- (2009c). Book Review of Robert Skidelsky (2009), Keynes: The Return of the Master (London: Allen Lane). The Guardian. 30 August 2009.

----- (2009d). 'How Did Economists Get It So Wrong?’ New York Times, 2 September.

----- (2009e). 'The Chinese Disconnect.' New York Times, 22 October.

Lau, Lawrence and Joseph Stiglitz (2005). 'China's alternative to revaluation.' Financial Times 24 April 2005.

Li, Huizhong, Ping Huang and Jialun Li (2007). 'China's FDI Net Inflow and Deterioration of Terms of Trade: Paradox and Explanation.' China and World Economy 15(1): 87-95.

Mahon, James E., Jr. (1992), 'Was Latin America too rich to prosper? Structural and political obstacles to export-led industrial growth.' Journal of Development Studies 28(2): 241263.

Palma, Gabriel (2003), 'The Latin American Economies During the Second Half of the Twentieth Century - from the Age of "ISI" to the Age of "The End of History,"' in Ha-Joon Chang (ed), Rethinking Development Economics. London: Anthem, pp. 125-148.

Pettis, Michael (2009). 'China's September Data Suggest that the Long-Term Overcapacity Problem is only Intensifying.' Emerging Markets Monitor, Roubini Global Economic Monitor, 21 October 2009, accessed on 22 October at http://www.rgemonitor.com/emergingmarketsmonitor/257856/chinas_september_data_suggest_that_the_longterm_overcapacity_problem_is_only_intensifying

Polanyi Levitt, Kari (2006). 'Keynes and Polanyi: the 1920s and the 1990s.' Review of International Political Economy 13(1): 152-177.

RGE (2009). 'Is Another Bubble in the Making? Could Central Banks Lose Control?' RGE Monitor, 21 November 2009.

Rodrik, Dani (2006). 'What's So Special about China’s Exports?' China and World Economy 14(5): 1-19. 
Rutton, Vernon W. (2006), Is War Necessary for Economic Growth? Military Procurement and Technology Development. Oxford: Oxford University Press.

Sachs, Jeffrey D. (1984). 'Comment and Discussion.' Brookings Papers on Economic Activity 2: 393-401.

Shadlen, Ken (2006), 'Debt, Finance, and the IMF: Three Decades of Debt Crises in Latin America,' in South America, Central America and the Caribbean. London: Taylor and Francis, pp. 8-12.

Sun, Huayu (2009). 'Autonomy and Effectiveness of Chinese Monetary Policy under the De Facto Fixed Exchange Rate System.' China and World Economy 17(13): 23-38.

Sung, Yun-Wing (2007). 'Made in China: from world sweatshop to a global manufacturing centre?' Asian Economic Papers 6(3): 43-72.

Tily, Geoff (2009). 'The critical steps in the transition from the Treatise to the General Theory: an alternative interpretation.' Mimeo provided by the author, September 2009, forthcoming in History of Economic Issues, 2010.

Toye, John (1993). Dilemmas of development: Reflections on the counter-revolution in development theory and practice, $2^{\text {nd }}$ edition. Oxford: Basil Blackwell.

Triffin, Robert (1978/79). 'The International Role and Fate of the Dollar.' Foreign Affairs Winter 1978/79: 269-286.

UNCTAD. 2007. Trade and Development Report 2007. United Nations Conference on Trade and Development, Geneva.

Wade, Robert (2009). 'From Global Imbalances to Global Reorganisations.' Cambridge Journal of Economics 33:539-562.

Wang, Yajie, Hui, Xiaofeng \& Soofi, A.S. (2007). "Estimating renminbi (RMB) equilibrium exchange rate" Journal of Policy Modeling, Elsevier, vol. 29(3), pages 417-429.

Warren, Elizabeth, and Amelia Warren Tyagi (2004). The Two-Income Trap: Why Middle-Class Mothers and Fathers Are Going Broke. New York: Basic.

Wolf, Martin (2008). 'Keynes offers us the best way to think about the crisis.' Financial Times. 24 December 2008.

----- (2009a). 'It is in Beijing’s interests to lend Geithner a hand.' Financial Times, 9 June 2009.

----- (2009b). 'Why China must do more to rebalance its economy.' Financial Times, 22 September 2009.

----- (2009c). 'Grim truths Obama should have told Hu.' Financial Times, 17 November 2009.

Yang, X. \& Dou, X. (2004). 'Estimating of RMB equilibrium exchange: An approach of PPP.' China: Science Technique and Project. pp. 140-143.

Yao, Shunli (2009). 'Why are Chinese Exports Not So Special.' China and World Economy 17(1): 47-65.

Zhang, J. \& Fung H.G. (2006). "Winners or Losers: Assessing the Impact of Appreciation of Chinese Yuan” Journal of Policy Modeling, vol. 28, issue 9, pp. 995-1009.

Zheng, Yongnian, and Jingtao Yi (2007). 'China's Rapid Accumulation of Foreign Exchange Reserves and Its Policy Implications.’ China and World Economy 15(1):14-25. 